\title{
Editorial
}

\section{La Investigación en la Educación Universitaria en Pandemia}

\author{
Research in University Education in a Pandemic \\ Cleofé Genoveva Alvites Huamaní ${ }^{1}$ \\ https://orcid.org/0000-0001-6328-6470 \\ Editor en jefe de la revista científica Hamut'ay \\ Universidad Alas Peruanas, Perú
}

\section{Cita Recomendada}

Alvites-Huamaní, C., (2021). La investigación en la educación universitaria. Hamutay, 8 (3), pág 5-8, http://dx.doi.org/10.21503/hamu.v8i3.2344

\section{Introducción}

La pandemia que azota a nivel mundial y la que ha incidido en que la educación diera un giro abismal en todos los niveles, sobre todo a nivel universitario, al tener que reestructurar sus procesos de enseñanza y sus practicas investigativas ha hecho que se de una mira distinta a esta, en las que con mayor énfasis se han involucrado a los estudiantes, como capital humano de las universidades junto con los docentes (Dilas-Jiménez et al., 2020), quienes están haciendo que se reconozca y se valore el lado académico e investigativo con todo el aporte que están realizando para esta finalidad, tal como lo menciona Valencia-Rodríguez, (2013) al referirse que la gestión del conocimiento es la valoración del Know-how orientada a compartir el conocimiento, y sumado a ello es un activo de propiedad privada, que tiene un valor y con ello una capacidad de generar ingresos a los que la poseen, tanto material como académico e investigativo, (INS, 2010). Puesto que las universidades a nivel de país representan un $47 \%$ del gasto total en I+D en Perú, esto implica una relevancia en la contribución a generar conocimiento, (Dilas-Jiménez et al., 2020).

Siendo la investigación uno de los pilares de las universidades, tanto a nivel de pregrado y posgrado, por permitir la generación de conocimiento, entendida esta, según Valencia (2009) por las actividades e iniciativas específicas

\section{Introduction}

The pandemic that is hitting the world and the one that has affected education to take an abysmal turn at all levels, especially at university level, as they have to restructure their teaching processes and research practices has led to a look differently from this, it leads to students have been involved with greater emphasis, as human capital of the universities together with professors (Dilas-Jiménez et al., 2020), who are making it recognized and valued at what academic and research with all the contribution they are making to this objective, as mentioned by Valencia-Rodríguez, (2013) when referring that knowledge management is the assessment of Know-how aimed at sharing knowledge, added to it is an asset of private property, which has a value and with it a capacity to generate income for those who possess it, both material, academic and investigative (INS, 2010). Since universities at the country level represent $47 \%$ of total R\&D spending in Peru, which implies a relevance in the contribution to generating knowledge, (Dilas-Jiménez et al., 2020).

Research being one of the pillars of universities, both at the undergraduate and postgraduate level, for allowing the generation of knowledge, understood, according to Valencia (2009) activities and specific initiatives undertaken by higher-level institutions to increase their knowledge asset, which leads to give a higher

1.Editor en jefe de la revista científica Hamut’ay. Investigador Renacyt - Concytec. Universidad Alas Peruanas, Perú. revistahamutay@ uap.edu.pe 
emprendidaspor las instituciones denivel superior para aumentar su activo de conocimiento, lo cual conlleva a dar un mayor estatus a la academia. Junto a ello el perfeccionamiento que se ha ido realizando en la aplicación de las tecnologías y las nuevas perspectivas que se están dando a nivel universitario en el ámbito mundial por el cambio que se ha dado por esta crisis sanitaria, están incidiendo en la formación en investigación, para lo cual es necesario utilizar estrategias, recursos y herramientas acorde al avance de las tecnologías, al haber pasado a ser un recurso y herramienta en la interacción que se da en la formación en investigación.

Para Barbón y Fernández (2016) la formación en investigación es parte fundamental del proceso educativo universitario y del engranaje con el mundo laboral, ya que este permite comprender, interpretar y transformar la realidad, revirtiendo o solucionando el problema detectado. Dentro del cual los semilleros de investigación son una estrategia como espacio de formación y reflexión en torno a realizar investigación desde proyección y responsabilidad social, con lo que cumple con dos intencionalidades, lo primero desarrollar competencias investigativas en los estudiantes y lo segundo es apropiarse y aplicar los saberes específicos adquiridos en su proceso de enseñanza aprendizaje, Zambrano \& Peláez (2016).

La investigación en la educación universitaria en pandemia

Aunque se está pasando por momentos complicados a todo nivel, ya que hay una afectación en todos los ámbitos de la sociedad, la investigación no ha sido ajena, ya que en el caso de las ciencias sociales y la educación se ha tornado difícil realizar investigación, por una parte, por el tema de financiamiento y por otra por el confinamiento obligatorio que se tiene todavía (Lobo, 2020), a pesar de ello esto no ha sido una limitante, ya que muchos de los que realizan investigación en estas áreas se han reinventado y asumieron nuevos retos (Casanova, 2021), siendo su aliado las tecnologías de la información y status to the academy. In addition to this, the improvement that has been carried out in the application of technologies and the new perspectives that are taking place at the university level worldwide due to the change that has occurred because of this health crisis, are influencing research training, for which it is necessary to use strategies, resources and tools according to the advancement of technologies, having a resource and tool in the interaction that occurs in research training.

Barbón and Fernández (2016), said that research training is an inherent part of the university teaching-learning process and the engagement with the world of work, since it allows us to understand, interpret and transform reality, reversing or solving the detected problem. Within research seedbeds are a strategy as a space for training and reflection around conducting research from projection and social responsibility, which it fulfills two intentions, the first to develop investigative skills in students and the second is to appropriate and apply the specific knowledge acquired in their teaching-learning process, as Zambrano \& Peláez (2016) said.

\section{Research in university education in a pandemic}

Although it is going through complicated times at all levels, since there is an affectation in all society areas, research has been no strange, since in the case of social sciences and education it has become difficult to carry out research, due to the financing issue, and in the other hand, due to the mandatory confinement that is still in place (Lobo, 2020), despite this has not been a limitation, since many of those who carry out research in these areas have reinvented and assumed new challenges (Casanova, 2021), being their ally information and communication technologies (ICT), since new ways of collecting information have emerged in these areas, with the purpose of shoveling problems that have arisen by pandemic theme. The research comes to the fore and the media disseminates this knowledge, there is a massification of pre-prints in the dissemination of the research (Dal-Ré \& Morell, 2020), which 
comunicación (TIC), ya que han surgido nuevas formas de recolectar información en estas áreas, con la finalidad de palear problemáticas que han ido surgiendo por el tema de la pandemia. La investigación pasa a primer plano y los medios de comunicación divulgan este conocimiento, se da una masificación de los pre-print en la divulgación de la investigación (Dal-Ré \& Morell, 2020), lo que permite una retroalimentación de los interesados, lo cual ayuda a la investigación a corregir errores, y el acceso abierto a esta información. La tarea científica aumenta su visibilidad respecto a periodos anteriores (ColásBravo, 2021), ya que muchos investigadores se vieron forzados autocapacitarse en herramientas tecnológicas que les permitieran realizar trabajo de campo, a pesar de estar confinados y otros en aislamiento social. La pandemia si bien en un momento puso una pausa temporal al ámbito investigativo en las ciencias sociales y educativas, esto no fue definitivo, ya que ahora ha emergido y se muestra en crecimiento, (Ordorika, 2020). $\mathrm{Y}$ no solo se presentan resultados de estudios cuantitativos, sino de análisis cualitativos teniendo como medio a las tecnologías al permitir "el mantenimiento de redes de comunicación y colaboración entre investigadores, profesionales y participantes, poniendo la investigación una vez más al servicio de la salud colectiva desde el punto de vista del proceso (transferencia) y del contenido (conocimiento)", (Presado, Baixinho y Oliveira, 2021). Así como las revisiones sistemáticas (Dal-Ré \& Morell, 2020) y de enfoques mixtos.

\section{Referencias Bibliográficas:}

Barbón, O. y Fernández, J. (2016) Rol de la gestión educativa estratégica en la gestión del conocimiento, la ciencia, la tecnología y la innovación en la educación superior. Revista Educación Médica, 130.https://doi.org/10.1016/j. edumed.2016.12.001

Casanova, I. (2021). Importancia de la investigación durante la pandemia de Covid.19. Enfermería Investiga, 6(1), 1-2. https://doi. org/10.31243/ei.uta.v6i1.1020.2021 allows feedback from interested parties, which helps research to correct errors, and open access to this information. The scientific task increased its visibility compared to previous periods (ColásBravo, 2021), since many researchers were forced to self-train in technological tools that allowed them to carry out field work, despite being confined and others in social isolation. Although the pandemic at one point put a temporary pause in the research discipline in the social and educational sciences, this was not definitive, since it has now emerged and is growing (Ordorika, 2020). And not only are the results of quantitative studies presented, but also of qualitative analysis using technologies as a means by allowing "the maintenance of communication and collaboration networks between researchers, professionals and participants, putting research once again at the service of collective health from the point of view of the process (transfer) and content (knowledge)", (Presado, Baixinho and Oliveira, 2021). As well as systematic reviews (Dal-Ré \& Morell, 2020) and mixed approaches. 
Colás-Bravo, P. (2021). Retos de la Investigación Educativa tras la pandemia COVID-19. Revista de Investigación Educativa, 39(2), 319-333. https://doi.org/10.6018/rie.469871

Dal-Ré, R. \& Morell, F. (2020). The Covid-19 pandemic changes the scientific publication system.

Dilas-Jiménez, J.O., Ascurra-Toro, D. y MendozaPumapillo, J.E. (2020). Revista Llamkasun, 1(2), 69-76.https://doi.org/10.47797/llamkasun. v1i2.15

Instituto Nacional de Salud-INS, (2010). Lineamientos de política para la transferencia tecnológica en el Instituto Nacional de Salud: 2009-2014. Instituto Nacional de Salud de Perú y Ministerio de Salud.

Lobo, D. (2020). La investigación en tiempos de la pandemia del Covid-19. Revista Científica Universitaria Ciencias de la Salud, 7(1), 3-4.

Regueyra, M., Valverde-Hernández, M.yDelgado, A. (2021). Consecuencias de la Pandemia COVID-19 en la permanencia de la población estudiantil universitaria. Revista Actualidades Investigativas en Educación, 21(3), 1-30. https:// doi.org/10.1590/0034-7167.202174suppl101

Ordorika, I. (2020). Pandemia y educación superior. Revista de Educación Superior, 49, 1-8. https://doi.org/10.36857/resu.2020.194.1120

Presado, M., Baixinho, C. y Oliveira, E., (2021). Qualitative research in pandemic times. Revista Brasileña de Enfermería, 74(1). https://doi. org/10.1590/0034-7167.202174Suppl101

Scasso. C. y Medina, J. (2020). Desafios de las publicaciones científicas en la pandemia por el nuevo coronavirus (SARS-CoV-2). Revista Medica de Uruguay, 36(3), 22-26. https://doi. org/10.29193/RMU.36.3.9

Valencia, M. (2009) Modelo de Generación y transferencia de conocimiento en Pymes del Sector Cárnico de la ciudad de Cali.

Valencia-Rodríguez, M. (2013) Generación y transferencia de conocimiento. Revista Ingeniería Industrial, 34 (2), 178-187.

Zambrano, J. y Peláez, A. (2016) Las TIC en la investigación formativa en educación media: Una experiencia en la aproximación de niveles educativos. Revista Q, 11(21), 49-60. https://doi. org/10.18566/revistaq.v11n21.a04 